\title{
The Real-Time-Based Assessment of the Microbial Killing by the Antimicrobial Compounds of Neutrophils
}

\author{
J. T. Atosuo and E.-M. Lilius \\ Laboratory of Immunochemistry, Department of Biochemistry and Food Chemistry, University of Turku, \\ Vatselankatu 2, 20014 Turku, Finland
}

Received 31 August 2011; Accepted 3 November 2011

Academic Editor: Marco Antonio Cassatella

A recombinant Escherichia coli K-12 strain, transformed with a modified bacterial luciferase gene (luxABCDE) from Photorhabdus luminescens, was constructed in order to monitor the activity of various antimicrobial agents on a real-time basis. This E. coli-lux emitted, without any addition of substrate, constitutive bioluminescence $(\mathrm{BL})$, which correlated to the number of viable bacterial cells. The decrease in $\mathrm{BL}$ signal correlated to the number of killed bacterial cells. Antimicrobial activity of hydrogen peroxide $\left(\mathrm{H}_{2} \mathrm{O}_{2}\right)$ and myeloperoxidase (MPO) was assessed. In high concentrations, $\mathrm{H}_{2} \mathrm{O}_{2}$ alone had a bacteriocidic function and MPO enhanced this killing by forming hypochlorous acid $(\mathrm{HOCl})$. Taurine, the known $\mathrm{HOCl}$ scavenger, blocked the killing by MPO. When E. coli-lux was incubated with neutrophils, similar killing kinetics was recorded as in $\mathrm{H}_{2} \mathrm{O}_{2} / \mathrm{MPO}$ experiments. The opsonization of bacteria enhanced the killing, and the maximum rate of the MPO release from lysosomes coincided with the onset of the killing.

KEYWORDS: phagocytosis, neutrophil, myeloperoxidase, hydrogen, peroxide, hypochlorous, acid, bacterial, luciferase, bioluminescence 


\section{INTRODUCTION}

Polymorphonuclear neutrophils are the most abundant type of white blood cells in mammals; they are the key effector cells in the host defense response to microbial invasion providing the rapid deployment and effector arm of the immune system [1-6]. Neutrophils are professional phagocytes capable for ingesting microbes and particles into intracellular compartments called phagolysosomes.

An arsenal of cytotoxic agents in phagolysosomes is directed to degrade the phagocytosed material [7-10]. The process of opsonization is a means of identifying the invading microbes by phagocytes. The nonspecific binding of the complement component $\mathrm{C} 3 \mathrm{~b}$ and $\mathrm{C} 3 \mathrm{bi}$ and the specific binding of the serum antibodies to the invading pathogen are normally required for the successful recognition and destruction of this pathogen by phagocytic cell [11-16].

The ingestion of the target leads to enhanced consumption of oxygen through the activity of NADPH oxidase that generates superoxide anion $\left(\mathrm{O}_{2}{ }^{-}\right)$which is further dismutated forming hydrogen peroxide $\left(\mathrm{H}_{2} \mathrm{O}_{2}\right)$ [6-10]. This leads to the formation of further reactive oxidants such as hypochlorous acid $(\mathrm{HOCl})$ catalyzed by myeloperoxidase (MPO) $[6-9,17]$. MPO is a peroxidase enzyme having a fundamental role in the oxidant production and thus in antimicrobial activity of neutrophils. It is a lysosomal protein stored in azurophilic granules of the neutrophils [6-9]. MPO is released by fusing these granules with phagosome leading to the formation of the phagolysosome [18].

The assessment of the antimicrobial activities of neutrophils is generally made by flow cytometry (FC), chemiluminescence (CL) assay, or microscopy [13, 19-23]. Moreover, the detection of MPO is mainly based on the quantification of the enzyme protein by immunoassays without any knowledge of MPO activity. We have previously used luminol-amplified CL and FC to analyze the binding, ingestion and respiratory burst activities of phagocytes [24-28], and there is a strict correlation between the number of ingested particles and luminol-amplified CL response of neutrophils $[23,24]$, provided that the CL of adhesion events is excluded [23, 24]. Luminol-amplified CL has been shown to be almost completely dependent on the release of MPO from azurophilic granules.

These are reliable methods, but they do not reveal anything about the killing of the microbes. Conventionally, viability assessment is made by plate counting. The kinetic measurement of killing by this method is troublesome, and the results are not obtained on a real time basis, since the plates demand a long incubation period. Optical density (OD) measurement also provides a real-time assay, but the high cell density required for the turbidity measurements and an inability to distinguish between live and dead bacteria restrict the application of this method [29].

In this study, we describe an approach in which Escherichia coli K-12 pEGFPluxABCDEAmp (E. coli-lux) was utilized for the assessment of the killing by neutrophil-derived oxidants. We have previously shown that the bioluminescence (BL) signal of E. coli-lux was directly related to the number of viable bacterial cells and the diminishment of the signal, caused by the addition of antimicrobial agent, correlates to the number of killed E. coli-lux cells [29]. We can monitor this killing reaction quantitatively on a realtime basis by measuring the BL signal continuously during the incubation [29].

\section{MATERIALS AND METHODS}

\subsection{Materials}

Agar, tryptone, and yeast extract were obtained from Difco laboratories (Detroit, Mich). Disodium phosphate $\left(\mathrm{Na}_{2} \mathrm{HPO}_{4} \cdot 2 \mathrm{H}_{2} \mathrm{O}\right)$ and monopotassium phosphate $\left(\mathrm{KH}_{2} \mathrm{PO}_{4}\right)$ were purchased from J. T. Baker (Deventer, Holland). Ampicillin sodium salt, glycerol, $\mathrm{H}_{2} \mathrm{O}_{2}$, luminol, sodium chloride $(\mathrm{NaCl})$, and taurine were obtained from Sigma-Aldrich (St. Louis, Mo, USA). MPO was purchased from Planta Natural Products (Vienna, Austria). All reagents were at least of analytical grade. 


\subsection{Bacterial Preparation and Cultivation}

E. coli-lux was precultivated in $5 \mathrm{~mL}$ of Luria Bertani Broth (LB) (10 g tryptone, $5 \mathrm{~g}$ of yeast extract, $5 \mathrm{~g}$ $\mathrm{NaCl}$, and $\mathrm{pH} 7.4)$ and incubated in a shaker $(250 \mathrm{rpm})$ at $37^{\circ} \mathrm{C}$ overnight. Bacterial cultivation was then suspended in $100 \mathrm{~mL} \mathrm{LB}$ medium and incubated in a shaker $(250 \mathrm{rpm})$ at $37^{\circ} \mathrm{C}$ until $\mathrm{OD}_{620 \mathrm{~nm}}$ was 0.25 , measured with Shimadzu UV-1601 photometer (Shimadzu Corporation, Japan). At this OD, the cells were in logarithmic growth, and the cultures contained approximately $3.5 \times 10^{7}$ bacterial cells $/ \mathrm{mL}$. The cells were harvested by centrifugation at $2500 \times \mathrm{g}$, resuspended in the mixture of $20 \mathrm{~mL}$ of LB (containing $25 \%$ glycerol) for freezer stock to be stored at $-70^{\circ} \mathrm{C}$. All E. coli media contained $100 \mu \mathrm{g} / \mathrm{mL}$ ampicillin in order to maintain the selection pressure.

Before killing experiments, E. coli-lux was first cultivated by adding $50 \mu \mathrm{L}$ of freezer stock to $5 \mathrm{~mL}$ $\mathrm{LB}$ medium and then incubated in a shaker $(250 \mathrm{rpm})$ at $37^{\circ} \mathrm{C}$ until $\mathrm{OD}_{620 \mathrm{~nm}}$ was 0.25 . After incubation bacterial cells were harvested by centrifugation at $2500 \times \mathrm{g}$, washed two times, and then resuspended either in $67 \mathrm{mM}$ phosphate buffer ( $\mathrm{pH} 7.4$ ) with $0.9 \%$ sodium chloride $(\mathrm{NaCl})$ or Hanks Balanced Salt Solution (HBSS) with gelatin $(1 \mathrm{mg} / \mathrm{mL})$ (gHBSS) for phagocytosis analysis.

\subsection{Serum Handling and Leukocyte Separation}

Peripheral human blood was collected from a healthy volunteer into Venosafe $3 \mathrm{~mL}$ EDTA tube and one Venosafe $4 \mathrm{~mL}$ serum tube (Terumo Corporation, Leuven, Belgium). Serum was separated and used for the opsonization. $1 \mathrm{~mL}$ of EDTA blood was mixed with $10 \mathrm{~mL}$ of $0.83 \% \mathrm{NH}_{2} \mathrm{Cl}$ including $370 \mathrm{mg} / \mathrm{l}$ EDTA in order to lyse the red blood cells (RB). The suspension was kept at room temperature for $15 \mathrm{~min}$, after which leukocytes were separated by centrifugation for $10 \mathrm{~min}$ at $400 \times \mathrm{g}$. The lysed $\mathrm{RB}$ debris was sucked away, and leukocytes were resuspended in $1 \mathrm{~mL}$ of gHBSS. To avoid unnecessary stress to cells additional purification steps were refrained. Leukocytes were calculated with microscope by using Bürker counting chamber, and isolated leukocyte suspension contained approximately $2.5 \times 10^{6}$ neutrophils $/ \mathrm{mL}$, representing $85 \%$ of the phagocyte population (monocytes $12 \%$ and eosinophils $3 \%$ ). We have previously shown that the luminol-amplified CL response of monocytes and eosinophils is only $50 \%$ of that of neutrophils and, thus, practically, the entire CL-signal per blood volume originates from neutrophils [25].

\subsection{Antimicrobial Reaction of $\mathrm{H}_{2} \mathrm{O}_{2}$ and MPO}

Killing assays were performed by adding $140 \mu \mathrm{L}$ of cultivated $E$. coli-lux bacteria suspended in phosphate buffer ( $\mathrm{pH} 7.4$ with $0.9 \% \mathrm{NaCl}$ ), into the wells of a white clear bottom 96-well microtiter plate (Greiner BioOne, Düsseldorf, Germany), containing $3 \times 10^{5}$ or $3 \times 10^{6}$ bacterial cells/well. MPO ( 1 or $\left.2 \mu \mathrm{g} / \mathrm{well}\right), \mathrm{H}_{2} \mathrm{O}_{2}$ $(30 \mu \mathrm{M}, 125 \mu \mathrm{M}, 500 \mu \mathrm{M}, 2 \mathrm{mM}$, or $20 \mathrm{mM} /$ well $)$ and taurine $(50 \mathrm{mM} /$ well) were all added separately in $20 \mu \mathrm{L}$ of phosphate buffer. The final reaction volume was $200 \mu \mathrm{L} /$ well, and the reaction was started by adding $\mathrm{H}_{2} \mathrm{O}_{2}$.

\subsection{Killing Activity of Neutrophils}

Neutrophils-killing activity assay was performed by pipetting $100 \mu \mathrm{L}$ of cultivated bacteria suspended in gHBSS, containing $1 \times 10^{6}$ bacterial cells/well. Neutrophils were added by pipetting $2.5 \times 10^{5}$ neutrophils in $100 \mu \mathrm{L}$ of gHBSS into the wells. Opsonization was performed by adding $40 \mu \mathrm{L}$ of $2.5 \%$ serum solution in gHBSS to the reaction mixture, final serum concentration being $0.4 \%$. The final reaction volume was $250 \mu \mathrm{L} /$ well.

Luminol-amplified CL assay was made by adding $100 \mu \mathrm{L}$ of bacterial suspension $\left(1 \times 10^{6} \mathrm{E}\right.$. colilux cells/well) in gHBSS, $100 \mu \mathrm{L}$ of leukocyte suspension $\left(2.5 \times 10^{5}\right.$ neutrophils/well $)$ in gHBSS, $20 \mu \mathrm{L}$ of luminol (10 mM in borate buffer, $\mathrm{pH} 9.0)$, and $20 \mu \mathrm{L}$ of human serum solution in gHBSS to the microtiter plate wells (final serum concentration $0.4 \%$ ). The final reaction volume was $250 \mu \mathrm{L} /$ well. 


\subsection{Multimode Readers}

$\mathrm{BL}$ and $\mathrm{OD}(620 \mathrm{~nm})$ of E. coli-lux was measured in microtiter plate wells at $37^{\circ} \mathrm{C}$ in Mithras LB 940 microplate reader (Berthold technologies, Bad Wildbad, Germany). Luminol-amplified CL signal was measured in Chameleon microplate reader (Hidex, Turku, Finland), both controlled by MicroWin 2000 (Mikrotek). Three parallel wells were prepared from every reaction mixture. Readers were programmed to measure luminescence and OD continuously $0.5 \mathrm{sec} /$ well, at 60 or $240 \mathrm{sec}$ interval. Background signal was measured from a well containing only the buffer, and this reading was subtracted from the readings of the experimental wells. Results are shown as the mean \pm SD of three parallel wells.

\subsection{Colony Forming Unit (CFU) Measurement}

A duplicate microplate, similar to that placed into the multimode reader in $\mathrm{H}_{2} \mathrm{O}_{2} / \mathrm{MPO}$ and neutrophil analysis, was placed into a laminar hood and incubated at $37^{\circ} \mathrm{C}$. At $30 \mathrm{~min}$ intervals, $100 \mu \mathrm{L}$ of every reaction suspension was diluted $10^{1}-10^{7}$-fold, and $100 \mu \mathrm{L}$ and $20 \mu \mathrm{L}$ from every dilution were pipetted into Petri dishes containing LA agar with $100 \mu \mathrm{g} / \mathrm{mL}$ ampicillin. Colonies were counted after overnight incubation at $37^{\circ} \mathrm{C}$. Results are shown as CFU/reaction volume.

\subsection{Data Handling}

Raw data was analyzed in Excel version 2007 (Microsoft), and all graphs were prepared with Origin version 8 (Microcal).

\section{RESULTS}

\section{1. $\mathrm{H}_{2} \mathrm{O}_{2}$ and MPO Activity}

$\mathrm{H}_{2} \mathrm{O}_{2}$ and MPO were added into the E. coli-lux suspension $\left(3 \times 10^{5}\right.$ cells/well), and BL and CFU were recorded (Figure 1). $\mathrm{H}_{2} \mathrm{O}_{2}$ alone, in the absence of MPO, had a capacity of killing, and more than $99 \%$ of bacterial cells were killed by $500 \mu \mathrm{M} \mathrm{H}_{2} \mathrm{O}_{2}$ after $90 \mathrm{~min}$ of incubation (Figures 1(a) and 1(b)). Addition of MPO enhanced the killing substantially, since the addition of $1 \mu \mathrm{g}$ of MPO into $500 \mu \mathrm{M} \mathrm{H}_{2} \mathrm{O}_{2}$ killed more than $99 \%$ of bacterial cells already after one minute of reaction (Figures 1(a) and 1(b)). This enhancement was due to the $\mathrm{HOCl}$ generated by MPO reaction [7-10]. This was confirmed by adding $50 \mathrm{mM}$ taurine, the known $\mathrm{HOCl}$ scavenger [22, 30], which blocked the killing by MPO reaction nearly totally (Figure 1(a)). That the BL measurement and plate counting were in accord with each other is shown in Table 1.

Bacteriolytic effect of the antimicrobial agent is detectable only by assessing the decrease in the OD signal [31-33]. The OD detection limit of the used plate reader, for the bacterial suspension, was approximately $1 \times 10^{6}$ cells/well corresponding to 0.030 OD in $200 \mu \mathrm{L}$, and therefore 10 -fold higher bacterial cell number $\left(3 \times 10^{6}\right.$ cells/well $)$ had to be used in killing experiments. The $\mathrm{H}_{2} \mathrm{O}_{2}$ concentrations used in previous experiments were not high enough to show any decrease in OD. Only $2 \mathrm{mM}_{2} \mathrm{O}_{2}$ in the presence of $2 \mu \mathrm{g}$ of MPO and $20 \mathrm{mM} \mathrm{H}_{2} \mathrm{O}_{2}$ in the absence of MPO showed a decrease in OD, that is, bacteriolysis (Figure 2). In summary, the antimicrobial agents of neutrophils, $\mathrm{H}_{2} \mathrm{O}_{2}$, and $\mathrm{HOCl}$ showed significant killing capacity, which was easily measurable using E. coli-lux. These agents in high concentrations were even able to lyse the bacterial cells.

\subsection{Killing Activity of Neutrophils}

When neutrophils, instead of $\mathrm{H}_{2} \mathrm{O}_{2}$ and MPO, were added to the reaction, similar killing curves (Figure 3) were recorded as in previous experiments. It is noteworthy that neutrophils quenched partially BL since the 


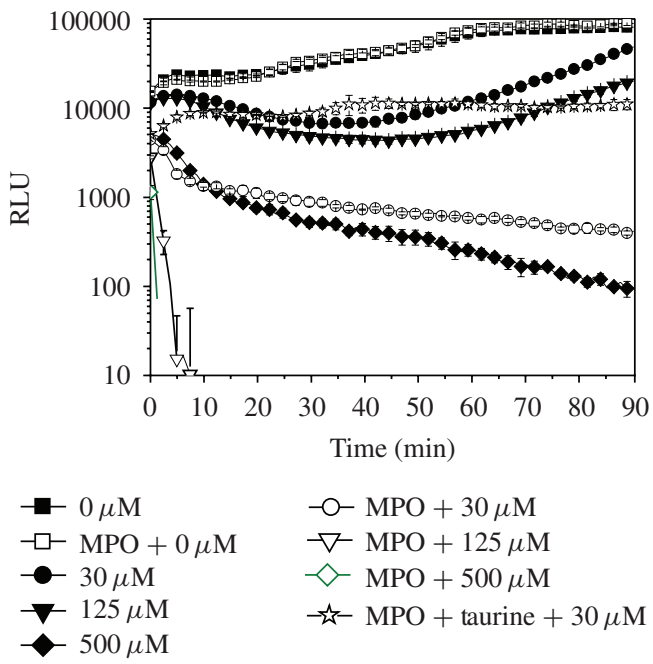

(a)

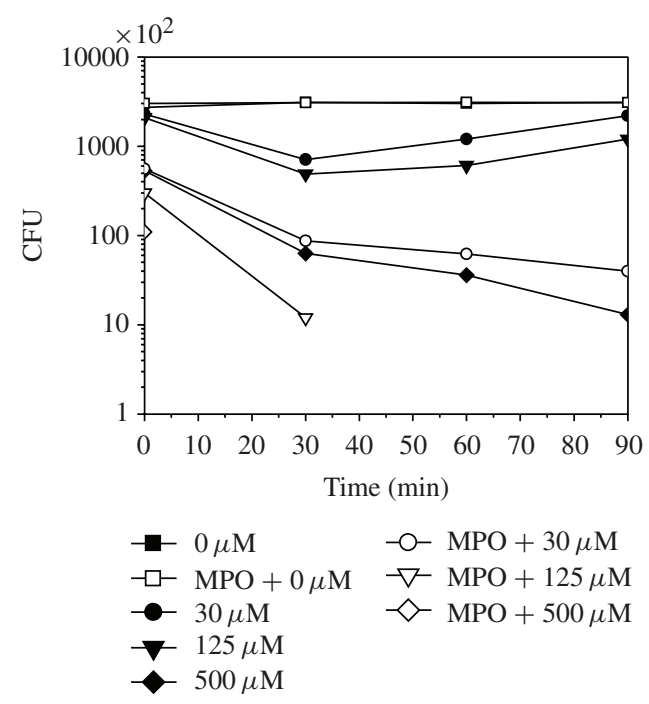

(b)

FIGURE 1: The bioluminescence signal (a) and colony forming units (CFU)/200 $\mu \mathrm{L}$ (b) of E. coli-lux $(3 \times$ $10^{5}$ cells) incubated in the presence of various amounts of $\mathrm{H}_{2} \mathrm{O}_{2}(\mu \mathrm{M})$ and $1 \mu \mathrm{g} /$ well MPO in phosphate

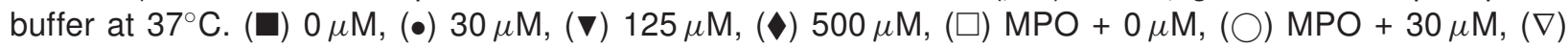
$\mathrm{MPO}+125 \mu \mathrm{M},(\diamond) \mathrm{MPO}+500 \mu \mathrm{M}$, and $(\square) \mathrm{MPO}+50 \mathrm{mM}$ of taurine $+30 \mu \mathrm{M}$. Relative luminescence unit $(R L U)$ values are shown as the mean $\pm S D$ of measurements from three parallel wells.

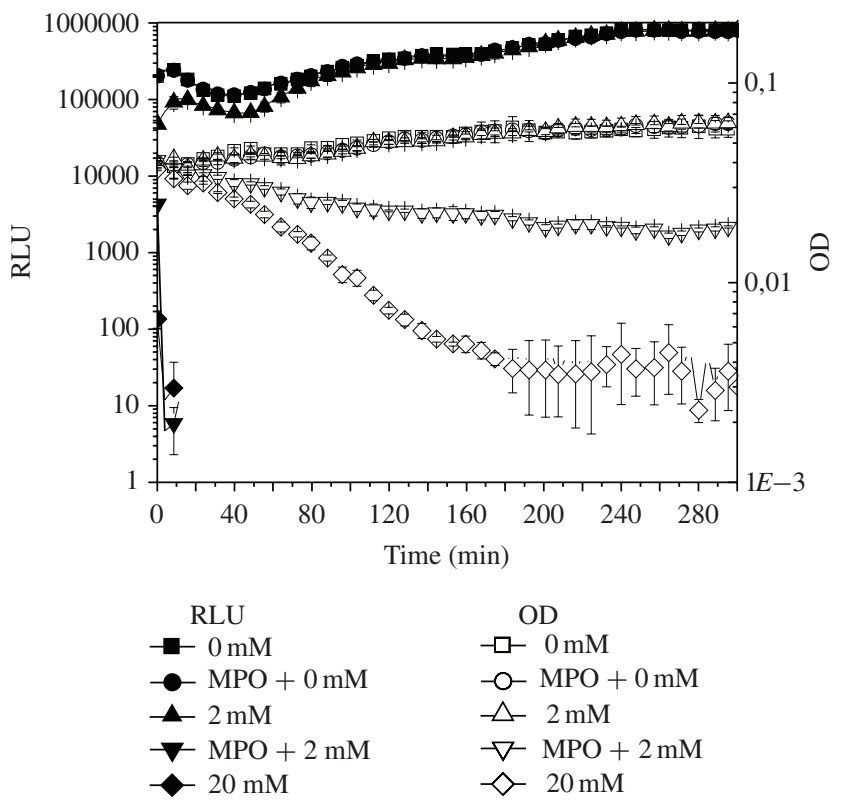

FIGURE 2: The bioluminescence signal and optical density (OD) of $E$. coli-lux $\left(3 \times 10^{6}\right.$ cells) incubated in the presence of various amounts of $\mathrm{H}_{2} \mathrm{O}_{2}(\mathrm{mM})$ and $2 \mu \mathrm{g} /$ well MPO in phosphate buffer at $37^{\circ} \mathrm{C}$. RLU: (ם) $0 \mathrm{mM},(\bullet) \mathrm{MPO}+0 \mathrm{mM},(\boldsymbol{\Delta}) 2 \mathrm{mM},(\boldsymbol{\nabla}) \mathrm{MPO}+2 \mathrm{mM}$, and $(\diamond) 20 \mathrm{mM} ; \mathrm{OD}_{620 \mathrm{~nm}}:(\square) 0 \mathrm{mM},(\bigcirc) \mathrm{MPO}+0 \mathrm{mM}$, $(\triangle) 2 \mathrm{mM},(\nabla) \mathrm{MPO}+2 \mathrm{mM}$, and $(\diamond) 20 \mathrm{mM}$ of $\mathrm{H}_{2} \mathrm{O}_{2}$. Relative luminescence unit (RLU) and OD values are shown as the mean \pm SD of measurements from three parallel wells. 
TABLE 1: The killing capacity of the $\mathrm{H}_{2} \mathrm{O}_{2}$ /MPO system. The killing capacity of the $\mathrm{H}_{2} \mathrm{O}_{2}$ /MPO system, both from the RLU and CFU analysis, was calculated by setting the values from the bacterial well as a $0 \%$ of killing.

\begin{tabular}{|c|c|c|c|c|c|c|c|c|}
\hline \multirow{3}{*}{ The killing capacity of the $\mathrm{H}_{2} \mathrm{O}_{2} / \mathrm{MPO}$ system } & \multicolumn{8}{|c|}{ Killing (\%) } \\
\hline & \multicolumn{2}{|c|}{$0 \min$} & \multicolumn{2}{|c|}{$30 \mathrm{~min}$} & \multicolumn{2}{|c|}{$60 \mathrm{~min}$} & \multicolumn{2}{|c|}{$90 \mathrm{~min}$} \\
\hline & RLU & $\mathrm{CFU}$ & RLU & $\mathrm{CFU}$ & RLU & $\mathrm{CFU}$ & RLU & CFU \\
\hline MPO $1 \mu \mathrm{g} /$ well & 0 & 0 & 0 & 1.3 & 0 & 0 & 0 & 0.6 \\
\hline $\mathrm{H}_{2} \mathrm{O}_{2} 30 \mu \mathrm{M}$ & 29.4 & 15.8 & 81.1 & 77.2 & 82.9 & 60.3 & 46.0 & 29.3 \\
\hline $\mathrm{H}_{2} \mathrm{O}_{2} 125 \mu \mathrm{M}$ & 29.4 & 23.1 & 86.5 & 84.2 & 91.4 & 79.8 & 78.0 & 61.4 \\
\hline $\mathrm{H}_{2} \mathrm{O}_{2} 500 \mu \mathrm{M}$ & 69.1 & 80.6 & 98.6 & 98.0 & 99.5 & 98.8 & 99.9 & 99.6 \\
\hline $\mathrm{H}_{2} \mathrm{O}_{2} 30 \mu \mathrm{M}+$ MPO $1 \mu \mathrm{g} /$ well & 72.9 & 79.5 & 97.6 & 97.2 & 99.1 & 98.0 & 99.6 & 98.7 \\
\hline $\mathrm{H}_{2} \mathrm{O}_{2} 125 \mu \mathrm{M}+\mathrm{MPO} 1 \mu \mathrm{g} /$ well & 82.4 & 89.0 & 100 & 99.6 & 100 & 100 & 100 & 100 \\
\hline $\mathrm{H}_{2} \mathrm{O}_{2} 500 \mu \mathrm{M}+\mathrm{MPO} 1 \mu \mathrm{g} /$ well & 93.2 & 96.0 & 100 & 100 & 100 & 100 & 100 & 100 \\
\hline
\end{tabular}

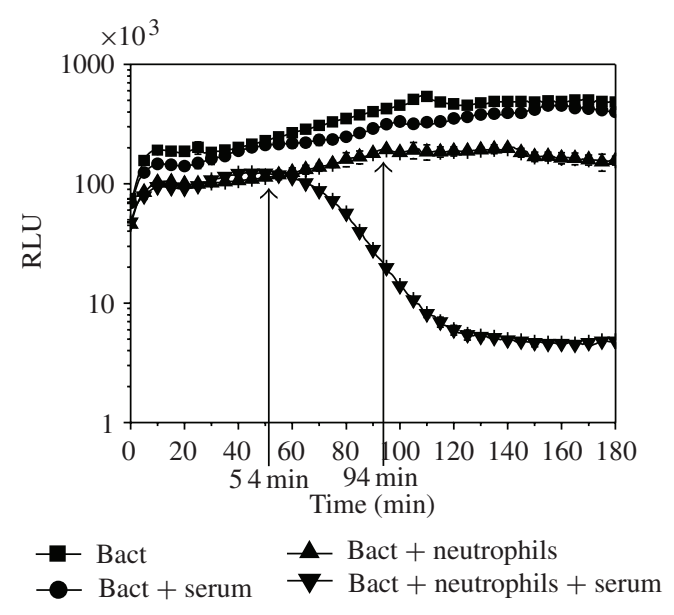

(a)

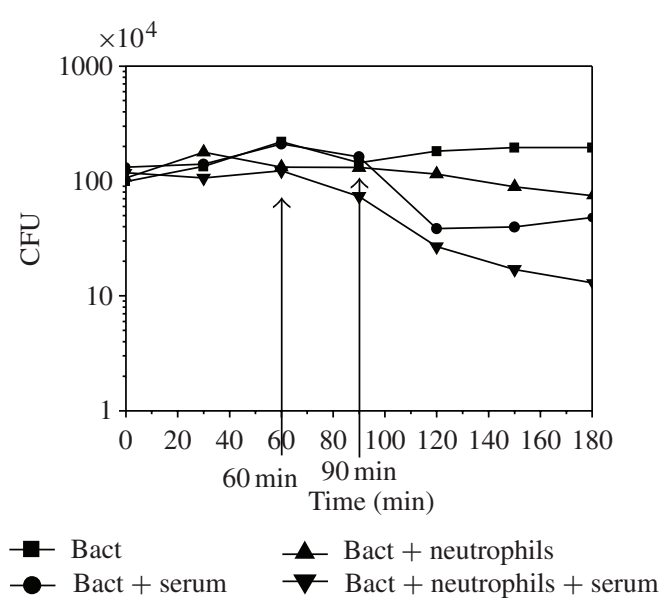

(b)

FIGURE 3: The bioluminescence signal (a) and colony forming units (CFU)/250 $\mu \mathrm{L}$ (b) of E. coli-lux $(1 \times$ $10^{6}$ cells) incubated in the presence of $2.5 \times 10^{5}$ neutrophils and $0.4 \%$ serum for opsonization in gHBSS medium at $37^{\circ} \mathrm{C}:(\boldsymbol{\square})$ bacteria, $(\bullet)$ bacteria + serum, $(\boldsymbol{\Delta})$ bacteria + neutrophils and $(\boldsymbol{\nabla})$ bacteria + neutrophils + serum. Relative luminescence unit (RLU) values are shown as the mean \pm S.D. of measurements from three parallel wells. Arrows point out the onset of the killing.

initial relative luminescence unit (RLU) value of bacteria was reduced by $40 \%$ instantly after adding $2.5 \times$ $10^{5}$ neutrophils into the mixture. This was not killing since CFU values did not instantly decrease.

The actual killing of the microbes started approximately after 50-60 min of incubation when $E$. coli-lux was opsonized with $0.4 \%$ serum (OPS) and after 90-100 min in the absence of opsonins (NOPS) (Figures 3(a) and 3(b)).

Killing rate after 180 min of measurement was $41 \%$ for NOPS and $96 \%$ for OPS measured by RLU (Figure 3(a)) and 49\% for NOPS and 92\% for OPS measured by CFU (Figure 3(b)). Leukocytes were disrupted to find out whether the ingested bacteria were killed. Since there was no difference between the disrupted samples and normal samples in RLU and CFU (data not shown), it was concluded that all the ingested bacteria were killed. 


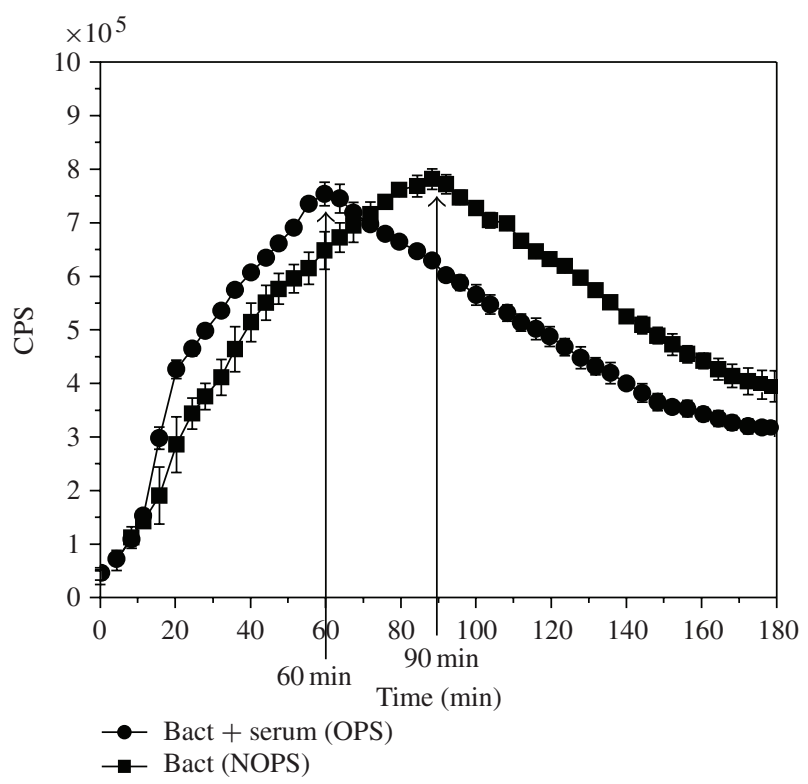

FIGURE 4: The luminol-amplified chemiluminescence $(C L)$ signal of E. coli-lux $\left(1 \times 10^{6}\right.$ cells $)$ with $2.5 \times$ $10^{5}$ neutrophils and $0.4 \%$ serum in gHBSS medium at $37^{\circ} \mathrm{C}$. (•) bacteria + serum (OPS) and $(\boldsymbol{\square})$ bacteria (NOPS). Counts per second (CPS) values are shown as the mean \pm SD of measurements from four parallel wells. Arrows point out the peak times of the $\mathrm{CL}$ signals.

Without neutrophils, the RLU signal was reduced by $4 \%$ in the presence of $0.4 \%$ serum (Figure 3(a)). The same reduction in CFU was $75 \%$ (Figure 3(b)). The discrepancy between these two values is thoroughly studied in another paper [29].

When luminol-amplified CL was recorded in the same reaction conditions as BL and CFU, the time to reach the maximum CL response (Figure 4) was the same as the time for the onset of killing (Figure 3).

\section{DISCUSSION}

E. coli-lux-based real-time BL measurement provides a new approach for the bacterial killing by neutrophils and also for the antimicrobial activity of MPO. The kinetics of the killing activity of the antimicrobial agents can be continuously recorded; hence, the conventional kinetic parameters such as $V_{\max }$ and $K_{m}$ can be obtained. From the kinetic curves, even the absolute number of the killed bacterial cells can be derived. It is obvious that the mechanisms of various scavenger and inhibitor functions, like taurine function in this study, can be explored.

In the present work, RLU and CFU values were in general in good correlation. Two exceptions were noticed. First, there was an initial reduction of $40 \%$ in RLU after the addition of neutrophils. This reduction was not present in CFU measurements. We have noticed that the extent of this reduction is dependent on the number of neutrophils added, even if they were heat inactivated (data not shown). The conclusion is that neutrophils somehow quench the BL of $E$. coli-lux either by absorbing the emission or by binding the bacteria, thus altering the BL properties.

The second exception was the reduction of CFU values caused by $0.4 \%$ serum (Figure 3(b)). Complement compounds present in this low serum concentration were transferred with the E. coli-lux cells into the plates and continued their activity during the overnight incubation, causing a considerable reduction in the bacterial viability in the plates. We have described this phenomenon earlier [29].

The lysis of the target $E$. coli-lux cells in the presence of $\mathrm{H}_{2} \mathrm{O}_{2}$ and/or $\mathrm{HOCl}$ was observed as a reduction in OD signal (Figure 2). These agents caused a rapid loss in viability (RLU values in Figures 1(a) 
and 2 and CFU values in Figure 1(b)) followed by much slower gradual lysis of the E. coli-lux (Figure 2). We will further study what are the mechanisms lying behind $\mathrm{H}_{2} \mathrm{O}_{2}$ - and $\mathrm{HOCl}$-induced lysis.

When the luminol-amplified CL assay (MPO release) was compared with viability assays, the maximum rate of the MPO release (the peak CL) coincided with the onset of the killing, suggesting that a certain threshold concentration of $\mathrm{HOCl}$ must be achieved before killing starts.

The results of this study suggest that the viability of $E$. coli-lux can be assessed on a real-time basis quickly and efficiently without tedious and time-consuming plate counting.

\section{REFERENCES}

[1] K. L. Anderson, K. A. Smith, F. Pio, B. E. Torbett, and R. A. Maki, "Neutrophils deficient in PU.1 do not terminally differentiate or become functionally competent," Blood, vol. 92, no. 5, pp. 1576-1585, 1998.

[2] J. G. Lieber, S. Webb, B. T. Suratt et al., "The in vitro production and characterization of neutrophils from embryonic stem cells," Blood, vol. 103, no. 3, pp. 852-859, 2004.

[3] F. Hayashi, T. K. Means, and A. D. Luster, “Toll-like receptors stimulate human neutrophil function,” Blood, vol. 102, no. 7, pp. 2660-2669, 2003.

[4] M. A. Cassatella, M. Locati, and A. Mantovani, "Never underestimate the power of a neutrophil," Immunity, vol. 31, no. 5, pp. 698-700, 2009.

[5] D. C. Dale, L. Boxer, and W. C. Liles, "The phagocytes: neutrophils and monocytes," Blood, vol. 112, no. 4, pp. 935-945, 2008.

[6] S. J. Klebanoff, "Myeloperoxidase: friend and foe," Journal of Leukocyte Biology, vol. 77, no. 5, pp. 598-625, 2005.

[7] S. J. Klebanoff, "Myeloperoxidase-halide-hydrogen peroxide antibacterial system," Journal of Bacteriology, vol. 95, no. 6, pp. 2131-2138, 1968.

[8] E. B. Kurutas, O. Arican, and S. Sasmaz, "Superoxide dismutase and myeloperoxidase activities in polymorphonuclear leukocytes in acne vulgaris," Acta Dermatovenerologica Alpina, Pannonica et Adriatica, vol. 14, no. 2, pp. 39-42, 2005.

[9] K. M. Mullane, R. Kraemer, and B. Smith, "Myeloperoxidase activity as a quantitative assessment of neutrophil infiltration into ischemic myocardium," Journal of Pharmacological Methods, vol. 14, no. 3, pp. 157-167, 1985.

[10] P. Kumar, K. Pai, H. P. Pandey, and S. Sundar, "NADH-oxidase, NADPH-oxidase and myeloperoxidase activity of visceral leishmaniasis patients," Journal of Medical Microbiology, vol. 51, no. 10, pp. 832-836, 2002.

[11] J. Nuutila, U. Hohenthal, I. Laitinen et al., "Quantitative analysis of complement receptors, CR1 (CD35) and CR3 (CD11b), on neutrophils improves distinction between bacterial and viral infections in febrile patients: comparison with standard clinical laboratory data," Journal of Immunological Methods, vol. 315, no. 1-2, pp. 191-201, 2006.

[12] J. Nuutila, P. Jalava-Karvinen, U. Hohenthal et al., "CRP/CD11b ratio: a novel parameter for detecting grampositive sepsis," Human Immunology, vol. 70, no. 4, pp. 237-243, 2009.

[13] J. Nuutila and E. M. Lilius, "Flow cytometric quantitative determination of ingestion by phagocytes needs the distinguishing of overlapping populations of binding and ingesting cells," Cytometry Part A, vol. 65, no. 2, pp. 93-102, 2005.

[14] J. L. Carpentier, D. P. Lew, J. P. Paccaud et al., "Internalization pathway of C3b receptors in human neutrophils and its transmodulation by chemoattractant receptors stimulation," Cell Regulation, vol. 2, no. 1, pp. 41-55, 1991.

[15] A. S. Kemp and M. W. Turner, "The role of opsonins in vacuolar sealing and the ingestion of zymosan by human neutrophils," Immunology, vol. 59, no. 1, pp. 69-74, 1986.

[16] T. A. Gaither, C. H. Hammer, and J. E. Gadek, "Cleavage of membrane-bound C3b and C3bi by viable human neutrophils (PMN)," Molecular Immunology, vol. 20, no. 6, pp. 623-635, 1983.

[17] F. W. Asselbergs, J. W. C. Tervaert, R. A. Tio et al., "Prognostic value of myeloperoxidase in patients with chest pain," The New England Journal of Medicine, vol. 350, no. 5, pp. 516-518, 2004.

[18] C. Cougoule, P. Constant, G. Etienne, M. Daffé, and I. Maridonneau-Parini, "Lack of fusion of azurophil granules with phagosomes during phagocytosis of Mycobacterium smegmatis by human neutrophils is not actively controlled by the bacterium," Infection and Immunity, vol. 70, no. 3, pp. 1591-1598, 2002. 
[19] J. Nuutila, P. Jalava-Karvinen, U. Hohenthal et al., "Comparison of degranulation of easily mobilizable intracellular granules by human phagocytes in healthy subjects and patients with infectious diseases," Human Immunology, vol. 70, no. 10, pp. 813-819, 2009.

[20] R. Ihalin, J. Nuutila, V. Loimaranta, M. Lenander, J. Tenovuo, and E. M. Lilius, "Susceptibility of Fusobacterium nucleatum to killing by peroxidase-iodide-hydrogen peroxide combination in buffer solution and in human whole saliva," Anaerobe, vol. 9, no. 1, pp. 23-30, 2003.

[21] M. A. Cassatella, F. Mosna, A. Micheletti et al., "Toll-like receptor-3-activated human mesenchymal stromal cells significantly prolong the survival and function of neutrophils," Stem Cells, vol. 29, no. 6, pp. 1001-1011, 2011.

[22] L. Selloum, H. Djelili, L. Sebihi, and J. Arnhold, "Scavenger effect of flavonols on HOCl-induced luminol chemiluminescence," Luminescence, vol. 19, no. 4, pp. 199-204, 2004.

[23] V. Loimaranta, J. Nuutila, P. Marnila, J. Tenovuo, H. Korhonen, and E. M. Lilius, "Colostral proteins from cows immunised with Streptococcus mutans/S. sobrinus support the phagocytosis and killing of mutans streptococci by human leucocytes," Journal of Medical Microbiology, vol. 48, no. 10, pp. 917-926, 1999.

[24] S. Nikoskelainen, S. Verho, K. Airas, and E. M. Lilius, "Adhesion and ingestion activities of fish phagocytes induced by bacterium Aeromonas salmonicida can be distinguished and directly measured from highly diluted whole blood of fish," Developmental and Comparative Immunology, vol. 29, no. 6, pp. 525-537, 2005.

[25] E. M. E. Lilius and J. T. J. Nuutila, "Particle-induced myeloperoxidase release in serially diluted whole blood quantifies the number and the phagocytic activity of blood neutrophils and opsonization capacity of plasma," Luminescence, vol. 21, no. 3, pp. 148-158, 2006.

[26] A. Lojek, M. Ciz, P. Marnila, M. Duskova, and E. M. Lilius, "Measurement of whole blood phagocyte chemiluminescence in the Wistar rat," Journal of Bioluminescence and Chemiluminescence, vol. 12, no. 5, pp. 225-231, 1997.

[27] R. M. Roman, P. V. Camargo, F. K. Borges, A. P. Rossini, and C. A. Polanczyk, "Prognostic value of myeloperoxidase in coronary artery disease: comparison of unstable and stable angina patients," Coronary Artery Disease, vol. 21, no. 3, pp. 129-136, 2010.

[28] E. Cavusoglu, C. Ruwende, C. Eng et al., "Usefulness of baseline plasma myeloperoxidase levels as an independent predictor of myocardial infarction at two years in patients presenting with acute coronary syndrome," American Journal of Cardiology, vol. 99, no. 10, pp. 1364-1368, 2007.

[29] J. Atosuo, J. Lehtinen, L. Vojtek, and E.-M. Lilius, "Escherichia coli K-12 (pEGFPluxABCDEamp). A tool for analysis of bacterial killing by antibacterial agents and human complement activities on a real-time basis," submitted to International Journal of Antimicrobial Agents.

[30] S. Kearns and R. Dawson Jr., "Cytoprotective effect of taurine against hypochlorous acid toxicity to PC12 cells," Advances in Experimental Medicine and Biology, vol. 483, pp. 563-570, 2000.

[31] M. Rozenberg-Arska, J. C. Porsius, E. Y. Jaarsma, and J. Verhoef, "Bactericidal, bacteriolytic and opsonic activity of human serum against Escherichia coli," Journal of Medical Microbiology, vol. 22, no. 2, pp. 143-149, 1986.

[32] P. W. Taylor, "Sensitivity of some smooth strains of Escherichia coli to the bactericidal action of normal human serum," Journal of Clinical Pathology, vol. 27, no. 8, pp. 626-629, 1974.

[33] P. W. Taylor, "Bactericidal and bacteriolytic activity of serum against gram-negative bacteria," Microbiological Reviews, vol. 47, no. 1, pp. 46-83, 1983.

\section{This article should be cited as follows:}

J. T. Atosuo and E.-M. Lilius, "The Real-Time-Based Assessment of the Microbial Killing by the Antimicrobial Compounds of Neutrophils," TheScientific WorldJOURNAL, vol. 11, pp. 2382-2390, 2011. 

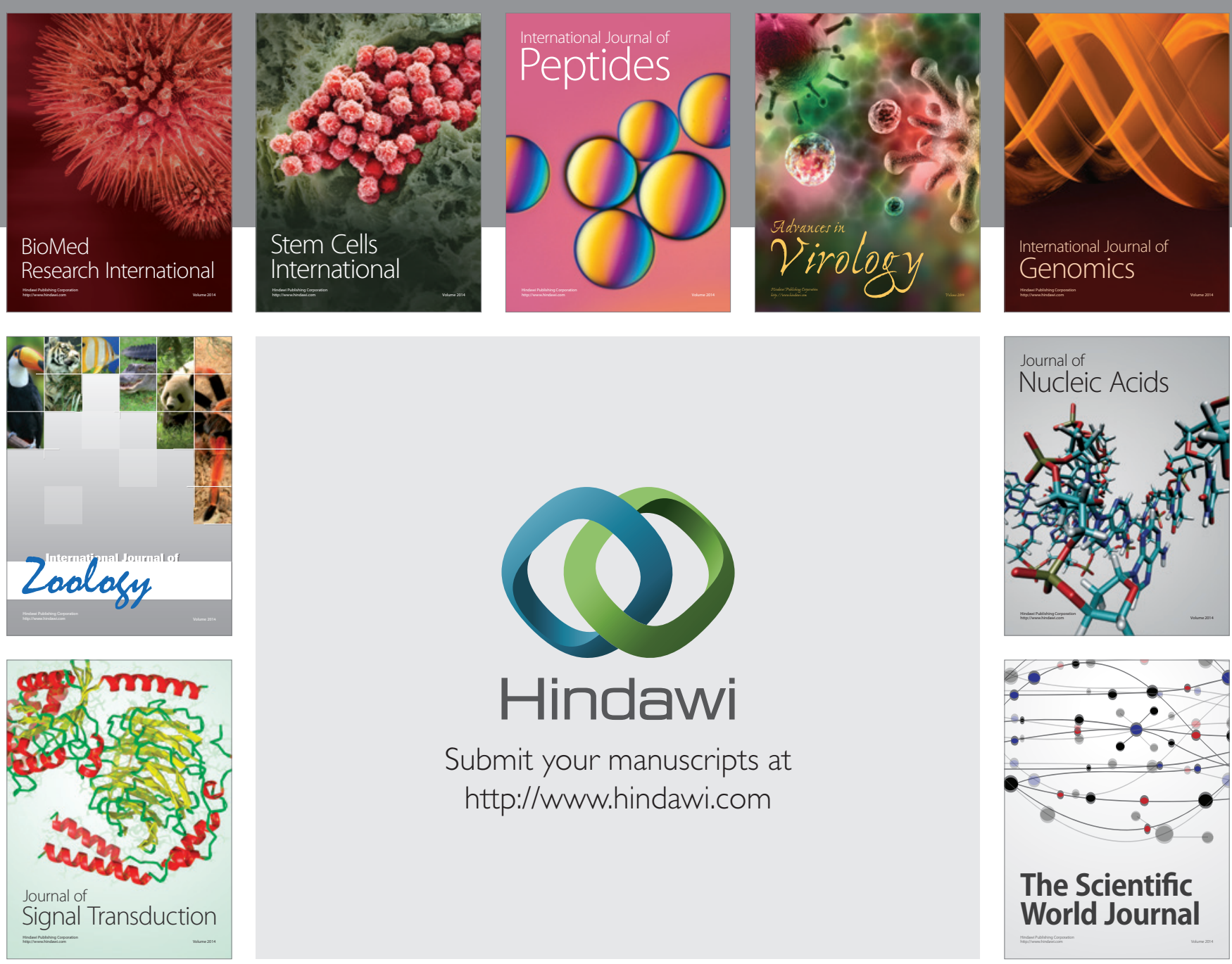

Submit your manuscripts at

http://www.hindawi.com
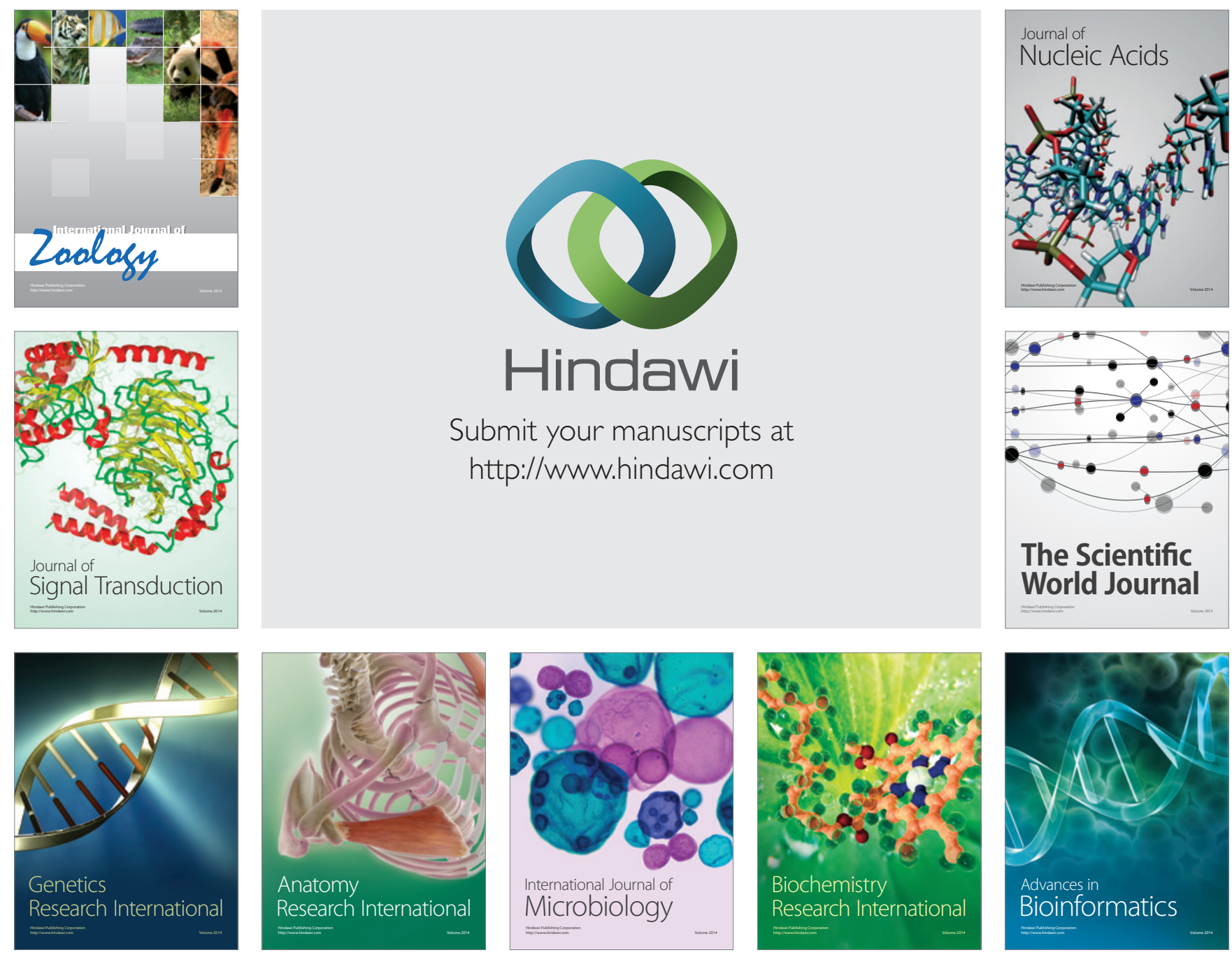

The Scientific World Journal
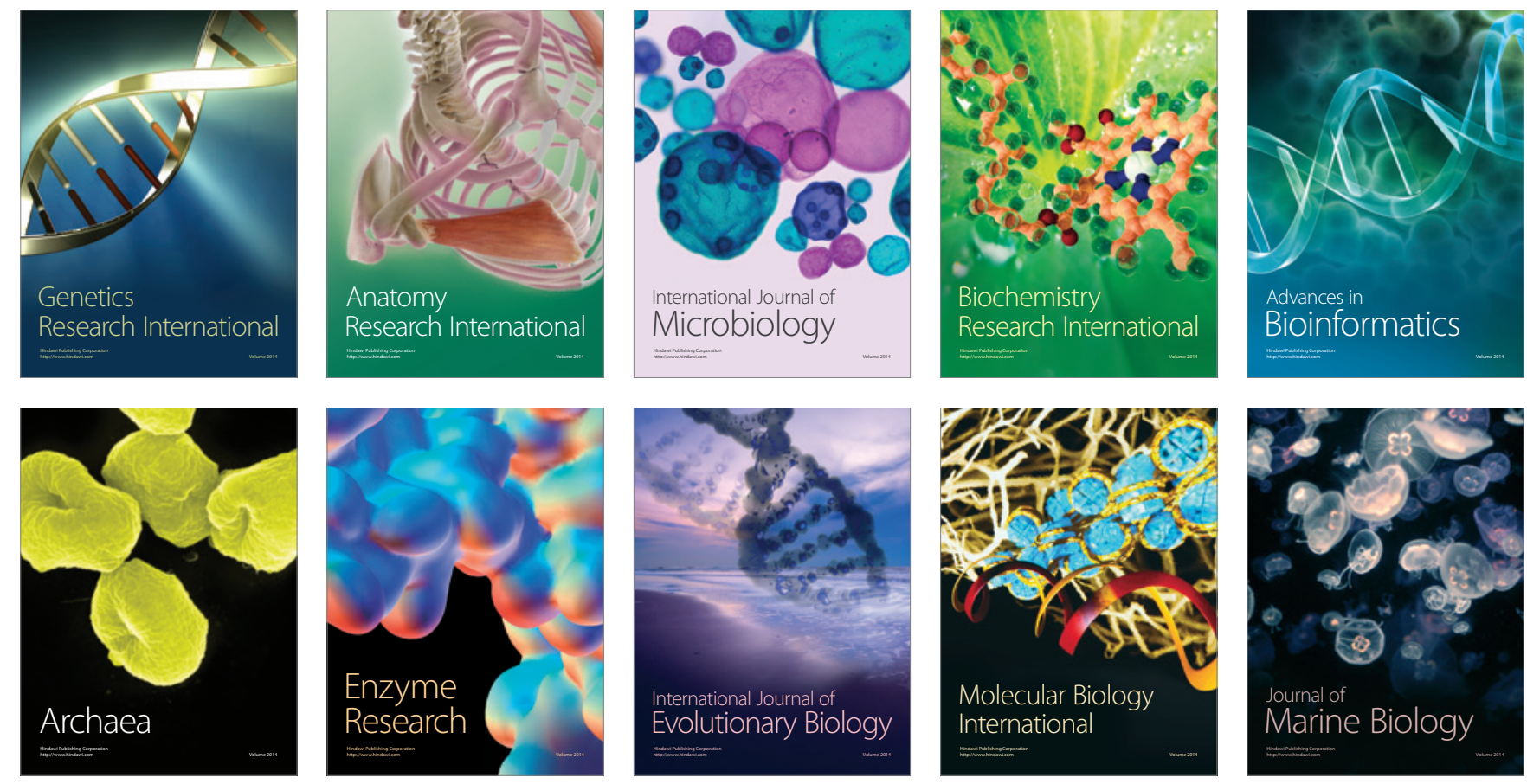